University of Nebraska - Lincoln

DigitalCommons@University of Nebraska - Lincoln

Faculty Publications: Department of Entomology

Entomology, Department of

1988

Comparison of Two Gelling Agents for Screwworm (Diptera:

Calliphoridae) Larval Diets

David B. Taylor

University of Nebraska-Lincoln, dave.taylor@ars.usda.gov

Follow this and additional works at: https://digitalcommons.unl.edu/entomologyfacpub

Part of the Entomology Commons

Taylor, David B., "Comparison of Two Gelling Agents for Screwworm (Diptera: Calliphoridae) Larval Diets" (1988). Faculty Publications: Department of Entomology. 212.

https://digitalcommons.unl.edu/entomologyfacpub/212

This Article is brought to you for free and open access by the Entomology, Department of at DigitalCommons@University of Nebraska - Lincoln. It has been accepted for inclusion in Faculty Publications: Department of Entomology by an authorized administrator of DigitalCommons@University of Nebraska - Lincoln. 


\title{
Comparison of Two Gelling Agents for Screwworm (Diptera: Calliphoridae) Larval Diets ${ }^{1}$
}

\author{
DAVID B. TAYLOR
}

USDA-ARS, Screwworm Research, Apartado 544, Tuxtla Gutierrez, Chiapas, Mexico

\begin{abstract}
J. Econ. Entomol. 81(5): 1414-1419 (1988)
ABSTRACT A sodium polyacrylamide polyacrylate gelling agent, Water-Lock G-400, and a galactan polysaccharide agent, carrageenan, were compared for solidifying larval diets of the screwworm, Cochliomyia hominivorax (Coquerel). Water-Lock diet produced larger pupae with less larval mortality than did carrageenan diet. Pupae from larvae reared on the Water-Lock diet exhibited higher emergence and produced adults with higher fecundity. Water-Lock diet also produced larger larvae at $56 \mathrm{~h}$ after oviposition. Densities in excess of $300 \mathrm{mg}$ of eggs (16,200 eggs) per liter of Water-Lock gelled diet did not increase larval yield but did reduce larval weight and survival
\end{abstract}

KEY WORDS Insecta, Cochliomyia hominivorax, gelled diets, mass rearing

AN ARTIFICIAL, MEAT-BASED, DIET for rearing screwworm larvae, Cochliomyia hominivorax (Coquerel), developed by Melvin \& Bushland (1936, 1940) was used relatively unchanged for mass production of screwworm until 1970. At that time, a liquid diet (hydroponic) supported by cotton or acetate fibers (Gingrich et al. 1971) was adopted. Because hydroponic diet was not suitable for rearing many small discrete lines of screwworms, meat diet was retained for research rearing.

Harris et al. (1984) tested several compounds for use as gelling agents to solidify the hydroponic diet of Gingrich et al. (1971). These authors reported that four gelling agents - Karaya Gum (Nutritional Biochemical), Norbak (Gelgard) (Dow Chemical), Gelcarin HWG (FMC Marine Colloids) (carrageenan), and casein (New Zealand Dairy Products) - yielded larvae comparable in size with those reared on the standard meat diet. Subsequently, Harris et al. (1985) examined four additional compounds, two sodium polyacrylate and two sodium polyacrylamide polyacrylate, copolymers. The sodium polyacrylamide polyacrylate gelling agent Water-Lock G-400 (Grain Processing Corp., Muscatine, Iowa), was considered most promising. Taylor \& Mangan (1987) compared flies reared on Water-Lock diet and the standard meat diet with respect to six life history parameters over several generations and found that they did not differ significantly. Because the gelled diet was cheaper, produced more uniform results, and was easier to use, it replaced meat diet for research rearing of screwworms.

Rearing screwworm larvae for mass production consists of two stages. The first, initiation, encom-

\footnotetext{
'This article reports the results of research only. Mention of a proprietary product does not constitute an endorsement or recommendation for its use by USDA.
}

passes the first $56 \mathrm{~h}$ after oviposition. Screwworm eggs are weighed, placed into Petri dishes with about $30 \mathrm{~g}$ of horse meat, and incubated for $8 \mathrm{~h}$. Eclosion occurs during this period. Contents of the Petri dishes are transferred to pans ( 46 by 33 by 5 $\mathrm{cm}$ deep) with 2 liters of hydroponic diet mixed with cotton (first initiation). Twenty-four hours later, larvae are transferred to larger pans ( 66 by 46 by $9 \mathrm{~cm}$ deep) with 4 liter of diet; they remain here for an additional $24 \mathrm{~h}$ (second initiation). For the second stage of larval rearing, larvae are transferred to vats ( 91 by 152 by $2.5 \mathrm{~cm}$ deep) on the main rearing floor. These vats contain an acetate fiber blanket soaked with hydroponic diet. Waste diet is vacuumed from the vats and replaced with fresh diet $8 \mathrm{~h}$ after the initial transfer and every $4 \mathrm{~h}$ thereafter for $3 \mathrm{~d}$. Mature larvae crawl off of the vats and fall into a collection system.

Gelled diet can be used in screwworm mass rearing for larval initiation, larval rearing, or both. In August 1986, the mass production facility (see acknowledgment) adopted hydroponic diet gelled by carrageenan for larval initiation. However, other than the summary data presented by Harris et al. (1984), no comparisons have been made between Water-Lock G-400 and carrageenan. The purpose of my study was to compare these two agents for initiation of culture and rearing throughout the larval stages of screwworm.

\section{Materials and Methods}

This study consisted of four separate experiments. In the first, I examined six screwworm life history parameters for larvae reared through to pupae on diets gelled with Water-Lock G-400 and carrageenan. In the second experiment, the two gelling agents were compared for larval initiation. The third repeated the second but under mass- 
production conditions; in the fourth experiment, the effect of density on larval production and weight during initiation was examined. The VF-84 strain of screwworms was used for all four experiments.

Nutrient concentrations for the Water-Lock and carrageenan-gelled diets were $70 \mathrm{~g}$ dried blood, $30 \mathrm{~g}$ dried egg, $30 \mathrm{~g}$ dried milk, and $1.2 \mathrm{ml}$ formol per liter of water. The Water-Lock diet was prepared by combining blood, egg, milk, and $12 \mathrm{~g}$ of Water-Lock G-400 and mixing the dry ingredients well. Formol was added to 1 liter of warm water $\left(35^{\circ} \mathrm{C}\right)$, which was then combined with the dry ingredients and mixed. The diet was allowed to set for 5 min before use. The carrageenan diet was prepared by combining blood, egg, milk, and formol with $500 \mathrm{ml}$ of water. Gelling agent was combined with $500 \mathrm{ml}$ of water and heated to boiling while being agitated. The hot gel and nutrient mixtures were combined, and single pan aliquots were poured into plastic pans. The carrageenan diet was allowed to set for $1 \mathrm{~h}$ before use.

Rearing techniques used for the first experiment were similar to those of Taylor \& Mangan (1987) for the Water-Lock diet. Three concentrations of carrageenan $(0.25,0.37$, and $0.5 \%)$ and Water-Lock (1.2\%) were examined with four pans for each treatment. One hundred mg of freshly oviposited screwworm eggs (approximately 2,700 eggs) and a small piece of fresh horse meat $(5 \mathrm{~g})$ were placed in a plastic Petri dish ( $9 \mathrm{~cm}$ diameter). The Petri dishes were placed on a metal rack $3 \mathrm{~cm}$ above a heated water bath $\left(39^{\circ} \mathrm{C}\right)$ (day 0$)$.

The next day (day 1 ), the piece of meat with first-instar larvae was transferred to a rearing pan with 0.5 liter of diet. Forty-eight and $72 \mathrm{~h}$ after transfer to diet, an additional 0.5 and 1 liter of diet, respectively, were added to the pans. Larval pans were maintained in a heated water bath $\left(37^{\circ} \mathrm{C}\right.$; air temperature approximately $28^{\circ} \mathrm{C}$; relative humidity $[\mathrm{RH}]$ uncontrolled 50-90\%). When mature larvae were observed on the surface of the diet (normally on day 5), larval pans were placed inside larger pans with $2 \mathrm{~cm}$ of sawdust covering the bottom. Larvae crawled off of the diet (crawl-off) and dropped into the sawdust. Five days after initial crawl-off, larval pans were discarded.

The day after crawl-off was complete (normally on day 11), pupae were sifted from the sawdust and a 10-ml sample was taken from each pan. The sample was weighed and the number of pupae was counted. Total volume of pupae per pan was also recorded. These data provided an estimate for total number of pupae per pan and mean pupal weight. The $10-\mathrm{ml}$ sample was placed in a small closed cup for determination of adult emergence and sex ratio. An additional $50 \mathrm{ml}$ of pupae from each pan were placed in an adult cage ( 15 by 30 by $12 \mathrm{~cm}$ ) for oviposition. The adults were provided water and honey ad libitum and induced to oviposit $8 \mathrm{~d}$ after initial adult emergence. Total weight of eggs oviposited per cage and percentage of egg hatch were recorded.
Eight pans of $0.25 \%$ carrageenan and $1.2 \%$ Water-Lock were prepared for the second experiment. Twenty-four and $72 \mathrm{~h}$ after infestation, four of the pans were scored. Scoring consisted of removing all living larvae from the diet and placing them in $95 \%$ alcohol, where the larvae were rinsed several times to eliminate as much diet as possible from the alcohol. As they were counted, they were transferred individually to clean alcohol. Larvae were maintained in alcohol for at least $48 \mathrm{~h}$ before being dried in an oven at $45^{\circ} \mathrm{C}$ for $24 \mathrm{~h}$. Dried larvae were weighed, giving alcohol-extracted dried weights.

The third experiment was performed in the screwworm mass-production facility, Tuxtla Gutierrez, Chiapas, Mexico. A 6\% blood, 3\% egg, 3\% milk diet was used for the Water-Lock and carrageenan-gelled diets. Water-Lock diet was prepared by combining $3,000 \mathrm{~g}$ dried blood, 1,500 $\mathrm{g}$ dried egg, 1,500 g dried milk, and $600 \mathrm{~g}$ gelling agent and mixing well. Water (43.350 liters) at $40^{\circ} \mathrm{C}$ and formol $(50 \mathrm{ml})$ were added to the dried products with agitation. Carrageenan diet was prepared by combining 10 liters of water with $125 \mathrm{~g}$ of carrageenan and heating the mixture to $80^{\circ} \mathrm{C}$. In a separate container, 33.825 liters of warm water $\left(40^{\circ} \mathrm{C}\right)$ was combined with $3,000 \mathrm{~g}$ blood, $1,500 \mathrm{~g}$ egg, and $1,500 \mathrm{~g}$ milk. Gel and nutrient mixtures were combined, and formol $(50 \mathrm{ml})$ was added with agitation.

Nine pans ( 66 by 46 by $9 \mathrm{~cm}$ deep) were prepared for each diet with 5 liters per pan. Nine cotton-hydroponic ( $6 \%$ blood, $3 \%$ egg, $3 \%$ milk) control pans ( 46 by 33 by $5 \mathrm{~cm}$ ) with 2 liters of diet were also prepared. Each pan was infested with $8 \mathrm{~g}$ of screwworm eggs, the density used for mass production at that time. For each diet, three pans were infested with fresh eggs on a patty of meat (approximately $30 \mathrm{~g}$ ), three were infested with fresh eggs without meat, and three were infested with eggs incubated for $8 \mathrm{~h}$ in covered Petri dishes $\left(15 \mathrm{~cm}\right.$ diameter) at $39^{\circ} \mathrm{C}$ on a meat patty before being transferred to the rearing pans. Cotton groups were transferred to larger pans (66 by 46 by 9 deep) with an additional 4 liter of diet at $32 \mathrm{~h}$ according to the standard production procedure. Pans were moved from the first initiation room $\left(38.9^{\circ} \mathrm{C}, 70 \% \mathrm{RH}\right)$ to the second $\left(37.8^{\circ} \mathrm{C}, 70 \% \mathrm{RH}\right)$ $32 \mathrm{~h}$ after oviposition. Gelled-diet groups were not given supplemental diet. In addition to the large pans, three small (19 by 16 by $9 \mathrm{~cm}$ deep) pans with $500 \mathrm{ml}$ of diet and $0.1 \mathrm{~g}$ of screwworm eggs were prepared for each diet. These were infested with incubated eggs and given no supplemental diet.

The experiment was terminated $56 \mathrm{~h}$ after oviposition. Larvae were normally transferred from initiation to the production floor at this age. A sample of larvae (approximately $3 \mathrm{~g}$ wet weight) was taken from each of the large pans, placed in 95\% alcohol, and processed as in experiment 2. Screwworm larvae were removed from the small 
Table 1. Comparison of screwworms reared on Water-Lock and carrageenan-gelled diets (Experiment 1)

\begin{tabular}{|c|c|c|c|c|}
\hline \multirow[b]{3}{*}{ No. pupae } & \multirow{2}{*}{$\begin{array}{c}\text { Water-Lock } \\
1.2 \% \\
\bar{x} \pm \mathrm{SD}\end{array}$} & \multicolumn{3}{|c|}{ Carrageenan } \\
\hline & & $\begin{array}{c}0.25 \% \\
\bar{x} \pm \mathrm{SD} \\
\end{array}$ & $\begin{array}{c}0.37 \% \\
\tilde{x} \pm \mathrm{SD}\end{array}$ & $\begin{array}{c}0.50 \% \\
\bar{x} \pm \mathrm{SD} \\
\end{array}$ \\
\hline & $1,771 \quad \pm 50.2 \mathrm{a}$ & $1,427 \pm 62.6 \mathrm{~b}$ & $1,004 \quad \pm 327.0 \mathrm{c}$ & $1,377 \quad \pm 38.2 \mathrm{~b}$ \\
\hline Pupal wt (mg) & $50.84 \pm 1.78 \mathrm{a}$ & $44.73 \pm 1.62 b$ & $42.44 \pm 3.15 b$ & $37.69 \pm 1.68 \mathrm{c}$ \\
\hline$\%$ emergence & $98.8 \pm 0.96 \mathrm{a}$ & $96.0 \pm 0.43 b$ & $95.9 \pm$ & $94.9 \pm 1.65 \mathrm{~b}$ \\
\hline$\%$ females & $49.1 \pm 1.60 \mathrm{a}$ & $49.0 \pm 1.92 \mathrm{a}$ & $47.7 \pm 1.87 \mathrm{ab}$ & $45.0 \pm 2.5 \mathrm{lb}$ \\
\hline Eggs (mg) & $469 \pm 94 a$ & $296 \pm 75 b$ & $357 \pm 128 \mathrm{ab}$ & $212 \pm 85 b$ \\
\hline$\%$ hatch & $89.60 \pm 2.2 \mathrm{la}$ & $91.32 \pm 1.55 a$ & $83.25 \pm . \quad 5.77 \mathrm{~b}$ & $88.49 \pm 2.83 \mathrm{ab}$ \\
\hline
\end{tabular}

Means in a row followed by the same letter do not differ significantly $(P>0.05$; Duncan's multiple range test [SAS Institute 1985]).

pans, placed into $95 \%$ alcohol, and again processed as in experiment 2 . The mean dry weight was calculated for the large pans. The number of larvae, total dry weight, and mean dry weight were recorded for each of the small pans. House flies frequently oviposit in initiation pans creating a nuisance on the rearing floor and possibly competing with the screwworm larvae for nutrients. The number of house fly larvae in each of the small pans was recorded.

The purpose of the fourth experiment was to examine the effect of density on larval survival and weight during initiation on Water-Lock diet prepared as for experiment 2. Eight densities (100, $200,300,400,500,600,700$, and $800 \mathrm{mg}$ of eggs per small pan [ 19 by 16 by $9 \mathrm{~cm}$ ] with 0.5 liter of diet) were examined. Larvae were removed from the pans $48 \mathrm{~h}$ after infestation, placed in $95 \%$ alcohol, and processed as in experiment 2. Total larval dry weight, number of larvae per pan, and mean larval dry weight were recorded.

Analysis of variance (ANOVA) (Proc GLM, SAS Institute 1985, 183-260) was used to determine the effect of diet on the six life history parameters examined in experiment 1 and on larval weight and survival for experiments 2, 3, and 4. Duncan's multiple-range test (Proc GLM, SAS Institute 1985) was used to separate the means for experiments 1 , 3, and 4. Linear regression (Proc GLM, SAS Institute 1985) was used to detect linear and curvilinear trends in larval weight and number for experiment 4. Statistical calculations were done with SAS-PC Version 6.02 on an IBM-PC computer equipped with an 8087 mathematical coprocessor.

\section{Results}

Screwworm larvae were reared to pupation on diets gelled with Water-Lock G-400 and three concentrations of carrageenan (Table 1). Six life history parameters-number of pupae (larval survival), pupal weight, percentage of adult emergence, percentage of females (sex ratio), weight of eggs laid per cage (fecundity), and percentage of egg hatch (fertility)-were examined. Of the three concentrations of carrageenan, $0.25 \%$ yielded the best results. Water-Lock diet produced significantly more pupae $(F=13.72 ; \mathrm{df}=3,12 ; P=0.0003)$, heavier pupae $(F=25.75 ; \mathrm{df}=3,12 ; P<0.0001)$, and higher adult emergence $(F=7.59$; $\mathrm{df}=3,12 ; P=$ 0.0042 ) than the carrageenan diets. Fecundity was highest. with the Water-Lock diet, but not significantly higher than the $0.37 \%$ carrageenan $\operatorname{diet}(F=$ $4.94 ; \mathrm{df}=3,12 ; P=0.0185)$. Percentage of hatch was reduced in eggs from flies reared on $0.37 \%$ carrageenan $(F=3.99 ; \mathrm{df}=3,12 ; P=0.0350$ ).

Use of the two gelling agents for larval initiation was compared in experiment 2. The number of larvae recovered from the pans at $24 \mathrm{~h}$ (WaterLock 1,239.5, SD = 171.99; carrageenan 1,303.2, $\mathrm{SD}=341.82)$ and $48 \mathrm{~h}$ (Water-Lock 1,464.2, SD = 232.91; carrageenan 1,335.5, $\mathrm{SD}=155.54$ ) did not differ significantly between Water-Lock and carrageenan diets $(F=0.111$; $\mathrm{df}=1,6 ; P=0.750$ : $F=0.845 ; \mathrm{df}=1,6 ; P=0.393$, respectively). However, larvae reared on Water-Lock diet were significantly heavier at $24 \mathrm{~h}(0.72 \mathrm{mg}, \mathrm{SD}=0.153)$ and $48 \mathrm{~h}(5.61 \mathrm{mg}, \mathrm{SD}=1.43)$ compared with those reared on the carrageenan diet $(0.42 \mathrm{mg}$, $\mathrm{SD}=0.103$ and $2.42 \mathrm{mg}, \mathrm{SD}=0.66)(F=10.497$; $\mathrm{df}=1,6 ; P=0.018: F=16.270 ; \mathrm{df}=1,6 ; P=$ 0.007 , respectively).

In experiment 3 , the two gelling agents were compared for use in initiation diets in the mass production facility at Tuxtla Gutierrez, Mexico. This test consisted of two parts, the first used standard production size pans infested with the same density of eggs as used for mass production $(8 \mathrm{~g}$ per 5 liters of diet). The second part replicated experiment 2 except that the pans were maintained in the production initiation room rather than in heated water baths of the research laboratory. The infestation system (direct with meat, direct without meat, and incubated with meat) (nested within diets) did not significantly affect larval dry weight at $56 \mathrm{~h}$ after oviposition $(F=2.45 ; \mathrm{df}=6,18 ; P=$ 0.065 ). Diet significantly affected larval dry weight $(F=12.47 ; \mathrm{df}=2,18 ; P=0.0004)$. Larvae reared on cotton-hydroponic control diet were heavier $(1.715 \mathrm{mg}, \mathrm{SD}=0.133)$ than those reared on WaterLock $(1.416 \mathrm{mg}, \mathrm{SD}=0.168)$ and carrageenan (1.376 mg, $\mathrm{SD}=1.33$ ) diets. Larval weight did not differ significantly between the two gelled diets.

Larval weight and survival were examined in the small pan portion of this test. The number of larvae per pan was not significantly affected by $\operatorname{diet}(F=0.960 ; \mathrm{df}=2,6 ; P=0.435)$ (Table 2). Diet significantly affected total dry weight of lar- 
Table 2. Comparison of screwworm larvae reared on cotton, Water-Lock, and carrageenan in small vats (Experiment 3)

\begin{tabular}{|c|c|c|c|}
\hline Diet & $\begin{array}{c}\text { No, of larvae } \\
\bar{x} \pm \mathrm{SD}\end{array}$ & $\begin{array}{c}\text { Total wt (g) } \\
\bar{x} \pm \mathrm{SD}\end{array}$ & $\begin{array}{c}\text { Mean wt (mg) } \\
\bar{x} \pm \mathrm{SD}\end{array}$ \\
\hline Cotton & $1,556.7 \pm 216.92 \mathrm{a}$ & $10.94 \pm 1.541 \mathrm{a}$ & $7.12 \pm 1.361 \mathrm{a}$ \\
\hline Water-Lock & $1,794.0 \pm 285.43 a$ & $11.99 \pm 2.423 \mathrm{a}$ & $6.69 \pm 0.743 a$ \\
\hline Carrageenan & $1,637.7 \pm 89.39 \mathrm{a}$ & $7.65 \pm 0.737 \mathrm{~b}$ & $4.67 \pm 0.215 b$ \\
\hline
\end{tabular}

Means in a column followed by the same letter do not differ significantly $(P>0.05$; Duncan's multiple range test [SAS Institute 1985])

vae per $\operatorname{pan}(F=5.227 ; \mathrm{df}=2,6 ; P=0.048)$ and mean larval dry weight $(F=6.312 ; \mathrm{df}=2,6 ; P=$ 0.033 ). Total dry weight and mean dry weight were significantly lower for larvae reared on carrageen-

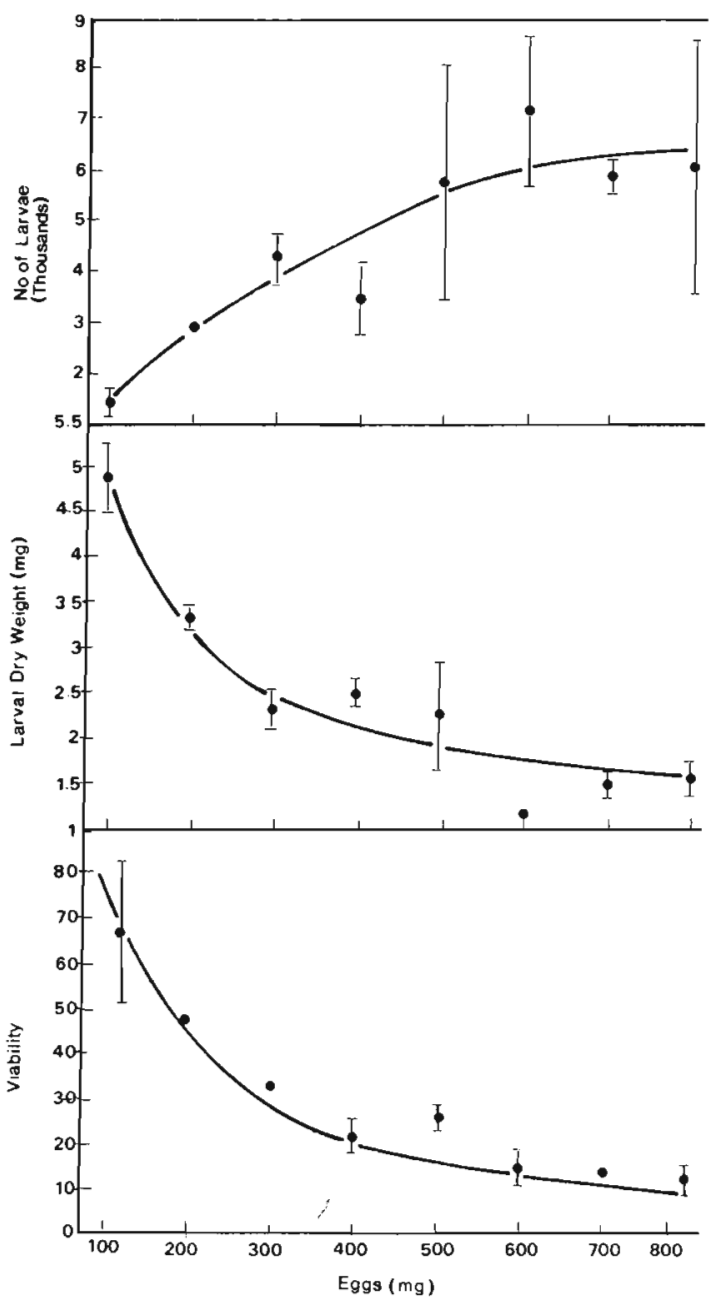

Fig. 1. Effect of density on larval survival (no, of larvae per pan), mean weight, and viability at $56 \mathrm{~h}$ after oviposition. Symbols represent treatment means, and vertical lines represent $\pm S D$. Lines represent linear regression models. Viability is dry weight of larvae recovered/weight of eggs planted. All groups were reared on Water-Lock (1.2\%) gelled diet. an diet. Density in the large pans was $1.6 \mathrm{~g}$ of screwworm eggs per liter of diet, while in the small pans it was $0.2 \mathrm{~g}$ per liter of diet. Mean dry weight of larvae reared in the small pans was approximately 4 times higher than that for larvae reared in the large pans at the higher larval density. These results indicated that larval density was a limiting factor on larval size for all three diets. No house fly larvae were observed in either of the two gelled diets. However, a mean number of 485 house fly larvae per pan was observed in the cotton-hydroponic control pans. House flies constituted 23.75\% of the dipterous larvae in those pans.

The final experiment examined the effects of larval density during initiation on larval weight. Water-Lock G-400 was used for this test. Total dry weight of larvae per pan was not significantly affected by density within the range of 100 to 800 mg of screwworm eggs per 0.5 liter of diet $(F=$ 2.24 ; $\mathrm{df}=7,8 ; P=0.140$ ). However, density significantly affected number of larvae per pan and mean larval dry weight $(F=28.67 ; \mathrm{df}=8,8 ; P<$ 0.0001 and $F=37.94 ; \mathrm{df}=7,8 ; P<0.0001$, respectively). The number of larvae increased curvilinearly relative to density of the eggs: number of larvae per pan $=16.039 \times \mathrm{mg}$ eggs $-0.010 \times$ $\operatorname{mg} \operatorname{eggs}^{2}\left(F=43.07 ; \mathrm{df}=2,14 ; P<0.0001 ; r^{2}=\right.$ 0.948) (Fig. 1). However, the number of larvae per pan did not increase significantly beyond $300 \mathrm{mg}$ of eggs per 0.5 liter of diet. Mean larval dry weight decreased curvilinearly relative to the reciprocal of the weight of eggs: mean dry weight $=1.138+$ $385.066 \times(1 / \mathrm{mg}$ eggs $),(F=117.73 ; \mathrm{df}=1,14$; $P<0.0001, r^{2}=0.894$ ). By dividing the total dry weight of larvae produced per pan by the weight of eggs in that pan, a measure of viability was derived. This measure represented the weight of larvae produced per unit of eggs. Viability varied significantly with respect to the weight of eggs per pan $(F=23.83$; df $=7,8 ; P<0.0001)$ and decreased curvilinearly with respect to the reciprocal of the weight of eggs (Viability $=7,765.4 \times[1 /$ mg eggs]: $F=305.52 ; \mathrm{df}=1,15 ; P<0.0001 ; r^{2}=$ $0.953)$.

\section{Discussion}

Tests comparing Water-Lock and carrageenangelled diets for small scale and mass production of screwworm larvae indicated that the Water-Lock diet was superior for both larval initiation (first 
$56 \mathrm{~h}$ ) and larval rearing (remaining portion of larval stage). Use of Water-Lock resulted in larger pupae, lower mortality, and higher adult emergence than did carrageenan. At the high larval density used for screwworm mass production (1.6 g of eggs per liter of diet) liquid diet suspended in cotton produced the largest larvae at $56 \mathrm{~h}$. The two gelled diets produced smaller larvae and did not differ significantly at this density. However, at the reduced larval density $(0.2 \mathrm{~g}$ of eggs per liter of diet) larvae reared on Water-Lock and cotton-hydroponic diets were larger than those reared on the carrageenan diet.

Results of experiment 4 indicated that the number of larvae produced per initiation pan did not increase significantly beyond an infestation rate of $300 \mathrm{mg}$ of eggs per 0.5 liter of diet (about one-third of the infestation rate used by production at that time, before August 1986). The primary effect of higher infestation rates was decreased survival and reduced larval weight. High mortality increases the possibility of selection for adaptation to mass production and possibly accelerates the rate at which strains became overly adapted to the mass-rearing environment and lose their field competitiveness.

In June 1986, managers of the screwworm massproduction facility changed from cotton to carrageenan gel as the support matrix for hydroponic diet in initiation and later reduced the initiation density from $8 \mathrm{~g}$ of screwworm eggs per 5 liters of diet to $3 \mathrm{~g}$ per 4 liters of diet. Mean weight of crawl-off larvae for the $16 \mathrm{wk}$ preceeding the change to carrageenan was $65.76 \mathrm{mg}$. Mean weight of crawl-off larvae during the $7 \mathrm{wk}$ of rearing on carrageenan at high initiation densities was 64.31 mg. Mean larval weight at crawl-off averaged 67.87 $\mathrm{mg}$ for $16 \mathrm{wk}$ of rearing on carrageenan at reduced initiation densities. With the reduced density system, each production vat received two initiation pans giving a density of $6 \mathrm{~g}$ of eggs per vat compared with $8 \mathrm{~g}$ previously. The volume of pupae recovered increased from 6.24 liters per vat with high density carrageenan ( 7.37 with high density cotton) to 8.06 liters per vat with reduced density carrageenan. Survival increased from 0.89 liter of pupae per gram of eggs with high density carrageenan initiation ( 0.97 with high density cotton) to 1.24 liters of pupae per gram of eggs with reduced density carrageenan initiation. These data support the conclusions of this study. When the production facility switched to carrageenan-gelled diet for initiation, larval weight and yield dropped slightly as in experiment 3. Moreover, weight and yield rose beyond their previous levels when initiation density was reduced as in experiment 4 .

The chemical structure and gelling mechanisms of Water-Lock and carrageenan differ greatly. Carrageenan is a galactan polysaccharide extracted from certain species of red algae (Rhodophyceae). Carrageenan gel appears to be sensitive to the ambient humidity. The gel dries rapidly in low humidities and becomes watery at high humidities.
Carrageenan solidifies the diet through the formation of double-stranded, cross-linked helixes. Water remains free, suspended in the helixes, permitting water-soluble molecules such as ammonia to disperse freely throughout the gel matrix (Sand 1982). Consequently, unused diet becomes contaminated by metabolic wastes rendering it unfit for consumption. Furthermore, the gel, liquefied by larval feeding, emits an odor of sulfur and ammonia.

Water-Lock is a hydrophilic polyacrylonitrile polymer that acts as an absorbent. The consistency of Water-Lock diet remains relatively constant over a wide range of humidities, although mixing or incubating it at temperatures above $40^{\circ} \mathrm{C}$ cause the diet to exude water and become rubbery. Little free water is available in a $1.2 \%$ gel such as the one used for this study. Because of the lack of free water, water-soluble metabolic wastes such as ammonia do not diffuse into the unused portions of the diet. Thus, Water-Lock diet remains semisolid, emits little odor, and is acceptable to screwworm larvae for a longer time before becoming contaminated by toxic waste products.

Gelled diets were effective for the initiation phase of screwworm mass production. Their use eliminated the need to refeed initiation pans at $24 \mathrm{~h}$ and reduced the suitable habitat for housefly breeding. Water-Lock was superior to carrageenan biologically and in terms of labor, time, and energy required for preparation. Water-Lock does not require heating and can be used immediately, whereas carrageenan must be heated to at least $80^{\circ} \mathrm{C}$ and cooled for more than $1 \mathrm{~h}$ before use.

Although neither of the gelled diets was tested for rearing the entire larval stage under mass-production conditions, gelled diets have several advantages over acetate-hydroponic diet. Currently, waste diet must be removed and replenished with fresh diet every $4 \mathrm{~h}$, for a total of 23 feedings during the larval stage. An equivalent system with gelled diet eliminates the need to remove the waste diet and reduces the number of feedings to three. The acetate-hydroponic feeding schedule requires $24 \mathrm{~h}$ per day attention. A gelled-diet system requires attention only once per day, eliminating the need for three full shifts a day in the mass-production facility. In addition, the efficiency of larval collection is higher with a gelled-diet system. With the current system, a significant number of larvae do not crawl off of the acetate mats and are destroyed when the vats are cleaned. With a gelled-diet system, the gel could be strained before disposal, thus collecting $100 \%$ of the larvae. Although WaterLock gelling agent is 5 to 6 times more expensive than acetate per liter of pupae produced, results of small-scale tests indicate that the 25 to 50 liters of diet required to rear 1 liter of pupae with the acetate-hydroponic system (depending upon larval survival and pupal yield) could be reduced to 15 to 22 liters of diet with a Water-Lock gelled-diet system. Savings in diet ingredients alone offset the 
additional cost of the gelling agent. Additional savings can be expected from the reduced labor and energy requirements of the gelled-diet system.

\section{Acknowledgment}

I thank J. W. Mackley, R. L. Harris, and N. C. Leppla for their helpful suggestions and critical reading of the manuscript and Comision Mexico-Americana para la Erradicacion del Gusano Barrenador del Ganado for the use of its facilities and access to its rearing records.

\section{References Cited}

Gingrieh, R. E., A. J. Graham \& B. G. Hightower. 1971. Media containing liquefied nutrients for massrearing larvae of the screw-worm. J. Econ. Entomol. 64: 678-683.

Harris, R. L., R. D. Peterson III, M. E. Vazquez-Guevara \& O. H. Graham. 1984. Gelled media for the production of screwworm larvae. Southwest. Entomol. 9: 257-262.
Harris, R. L., E. F. Gersabeck, C. Corso \& O. H. Graham. 1985. Screwworm larval production on gelled media. Southwest. Entomol. 10: 253-256.

Melvin, R. \& R. C. Bushland. 1936. A method of rearing Cochliomyia americana $\mathrm{C}$. \& P. on artificial media. USDA, Bureau of Entomology and Plant Quarantine Report ET-88.

1940. The nutritional requirements of screwworm larvae. J. Econ. Entomol. 33: 850-852.

Sand, R. E. 1982. Nomenclature and structure of carbohydrate hydrocolloids, pp. 19-46. In M. Glicksman [ed.], Food hydrocolloids, vol. 1. CRC, Boca Raton, Fla.

SAS Institute. 1985. SAS/STAT guide for personal computers, version 6 ed. SAS Institute, Cary, N.C.

Taylor, D. B. \& R. L. Mangan. 1987. Comparison of gelled and meat diets for rearing screwworm larvae, Cochliomyia hominivorax (Diptera: Calliphoridae). J. Econ. Entomol. 80: 427-432.

Received for publication 30 September 1987; accepted 8 April 1988. 